\title{
Support for People with Disabilities within a Virtual Social Network: Rehabilitations Challenges for the $21^{\text {st }}$ Century
}

\author{
Fabiana Faleiros ${ }^{1 *}$, Yuri Leandro do Carmo de Souza ${ }^{2}$, Talita Rosa ${ }^{1}$, Viviam Rafaela Barbosa Pinheiro Freire ${ }^{2}$, \\ Fernando Augusto Ramos Pontes ${ }^{2}$ and Simone Souza Costa e Silva ${ }^{2}$
}

${ }^{1}$ University of São Paulo at Ribeirão Preto College of Nursing, Brazil

${ }^{2}$ Program in Behavior Theory and Research, Federal University of Pará, Brazil

Submission: April 27, 2017; Published: June 29, 2017

*Corresponding author: Fabiana Faleiros, University of São Paulo at Ribeirão Preto College of Nursing, Brazil, Email: fabifaleiros@eerp.usp.br

\begin{abstract}
This article reflects our view of how access to health information through social networks, especially at the virtual level, can promote development and assist the process of rehabilitation of people with disabilities. We will also present a promising innovation launched in 2017 in Brazil, aimed at improving access to quality health information, inducing social support networks and influencing the improvement of quality of life. It is intended that the virtual social platform " $\mathrm{D}^{+}$Eficiência" be an attractive technological tool that favors the formation of networks and transfer of knowledge between people with disabilities and their families. The " $\mathrm{D}^{+}$Eficiência" can be accessed through the link: http://www. demaiseficiencia.com
\end{abstract}

Keywords: Social networking; Technology; Development; Virtual network; Disabled persons

\section{Introduction}

Social Networks can be defined as a field where subjects are connected. They are also a set of people, organizations, institutions linked by some relation [1-6]. Since the 90s, network studies have been associated with the concepts of globalization, information society, cyber culture. Nowadays, however, they have been more related to concepts such as organizational networks, computer networks, and virtual networks, manifesting a new way of knowing, thinking and conceptualizing social reality. Virtual Social Networks can promote development and also establish links and develop strategies to support people with disabilities and their families. Thus, we believe that the social network of caregiver can function as a source of support to the family in biospicosocial aspects.

In turn, support can contribute significantly in the Family process of adaptation to the birth and child care with disabilities, often debated as a source of emotional, physical and financial burden. In this context, parents can to set aside personal goals because of child care, on these directions that the social network of caregivers may function as significant social support [7-10].

In Brazil, considering the extension of the country, some regions offer different living conditions, such as the Amazon region and the metropolitan region of São Paulo. These differences influence directly the functionality, autonomy and participation of people with disabilities, due to the difficulties and facilities of each context [11]. Another factor that influences the quality of life of people with disabilities is the difficulty of participation in society, for a lot of reasons, such as poor access to quality health information, to rehabilitation and accessibility centers [12].

In our view, virtual communities with health education in social media, can minimize the lack of information and connect people with disabilities in different regions of the country, as internet access is increasing worldwide today [13]. Thus, people with disabilities can benefit themselves from the use of virtual environments to achieve consistent health information that assists families in their care and social participation actions. In this collective learning context, individuals can obtain information and establish interactions with each other, exchanging information through discussion forums, which allow the emergence of support networks with people in the same situation or without leaving their [14-16].

In order to promote better dissemination of content that generates informational and emotional support, with consistent and scientific basis, also increasing interpersonal relationships 
among people with disabilities and their families, promoting autonomy, rehabilitation, empowerment and social participation, the virtual social network " $\mathrm{D}^{+}$Eficiência" was developed. The $\mathrm{D}^{+}$ Eficiência emerged through surveys initiated by Fabiana Faleiros since 2012, when clean intermittent auto-catheterism was evaluated in Brazilian and German people with spina bífida.

In this study it was possible to verify that the use of virtual forums by the German participants was considered as types of informational, emotional and professional support through the sharing of information and experience to individuals with spina bífida and their relatives [17]. The idea of developing this type of educational technology in Brazil emerged from that study. A tool called "MiéloForum" was developed and its goals were to promote informational support and to train people with spina bifida and their families. MiéloFórum is a virtual fórum for people with spina bifida and their families, with a structure composed by moderator, who manages discussions and creates topics with specific themes about spina bifida, such as treatment, news and curiosities. The user interaction consists of discussing the topics created by the moderator, but the user can also ask questions and share experiences about the topics [18].

Additional expectations of "MieloFórum" were to contribute to the development of other virtual forums about other disabilities. With the support of CAPES (Brazilian Federal Agency for Support and Evaluation of Graduate Education), it was possible to develop this totally innovative initiative that relies on the cooperation, transfer and sharing of technologies and experiences of researchers from three Brazilian universities: Universidade Federal do Pará, Federal University of Minas Gerais and University of São Paulo-Ribeirão Preto. It is emphasized that the development of this virtual social network has, initially, the scope of the entire Brazilian territory.

Therefore, considering the virtual social platforms as synthetic environments of high information flow and fundamental part of the contemporary daily life, the $\mathrm{D}^{+}$Eficiência was developed as a totally innovative initiative that will benefit disabled people and their families can share their personal experiences, find information with scientific basis, find social support and create networks among each other through usernetwork-user interaction besides institutions and professionals.

This virtual social network was developed to work in a fully responsive web environment, with a playful and friendly layout. In addition, aiming at user comfort, the structure of $\mathrm{D}^{+}$Eficiência combines elements of social networks and fórum which allow different types of interaction among users. $\mathrm{D}^{+}$Eficiência has a structural division that presents virtual communities with specific themes: cerebral palsy, public policies, spina bifida and autism. In these communities there are discussions whose moderators are professional experts in the topics.

The community is a virtual area directed and monitored by mediators who conduct themes through subtopics called discussions. All information presented is based on scientific evidence. In the discussions, participants can debate and comment on the topic in a free way, sharing previous experiences or knowledge, offering and receiving support from other users. This interaction user-network-user determines a pattern of knowledge exchange, empowering people on determined subjects, which is the social informational support. The news feed is another place where users can share information of their personal interest and experiences that they have had or they are experiencing at the moment. This is an environment in the virtual social platform that allows the posting of free themes according to the demand of the user.

\section{Final Considerations}

Social networks can play an important role in supporting families in a variety of situations, particularly in the case of disability. Studies like Mielofórum showed the need to strengthen social networks as support elements directed to produce knowledge and technology. With this, it is believed that $\mathrm{D}^{+}$Eficiência deepens the scientific knowledge in many types of disability through the induction of an accessible network of virtual support and learning, contributing to the rehabilitation and quality of life of people with disabilities training in the area of health and information technology. , besides to be used as way of professional

The $\mathrm{D}^{+}$Eficiência was launched in April 2017, and is already available at the link: http://www.demaiseficiencia.com/. In this virtual environment, several studies will be carried out to assess the effectiveness of induction of support networks, biopsychosocial aspects of people with disabilities and their families, as well as to evaluate the functionality of the network and to develop educational materials such as serius games, videos and Quiz to help the rehabilitation process.

\section{Acknowledgment}

The authors thank the Brazilian Federal Agency for Support and Evaluation of Graduate Education (CAPES) for the funding that enabled the development of this Virtual Network.

\section{References}

1. Barnes TJ (2003) The place of locational analysis: a selective and interpretive history. Progress in Human Geography 27(1): 69-95.

2. Fialho J (2015) Pressupostos para a construção de uma sociologia das redes sociais. Sociologia 29: 59-79.

3. Fialho JMR (2014) Análise De Redes Sociais: Princípios, Linguagem E Estratégias De Ação Na Gestão Do Conhecimento. Perspectivas em Gestão \& Conhecimento 4 (esp.): 9-26.

4. Mathias CLK (2014) Análise de Rede Social. INTERthesis: Revista Internacional Interdisciplinar 11(1): 131-146.

5. Burt RS (1992) Structural holes: the social structure of competition. Cambridge, Harvard University Press, USA, pp. 1-234.

6. Silveira MAP, Farina MC (2012) Análise de Redes Sociais como Ferramenta que Contribui para a Melhoria das Relações Entre Empresas Participantes de um APL de eventos. Redes 17(1): 33-54. 
7. Barbosa MAM, Balieiro MMFG, Pettengill MAM (2012) Cuidado Centrado Na Família no Contexto da Criança Com Deficiência e sua Família: Uma Análise Reflexiva. Texto e Contexto Enfermagem 2(1): 194-199.

8. Cunha KC, Souza YLCE, Silva SSC (2015) A importância da família para o desenvolvimento de crianças com a paralisia cerebral. In: Albuquerque RDL e Risuenho, S.E (Orgs). Inclusão de pessoas com deficiência no contexto amazônico, L\&A Editora, Belém, Brazil.

9. Dezoti AP, Alexandre AMC, Freire MHS, Mercês NNA, Mazza VA (2015) Apoio social a famílias de crianças com paralisia cerebral. Acta Paulista de Enfermagem 28(2): 172-176.

10. Freire VRBP, Souza PBM, e SIlva SSC (2015) Reflexões sobre crenças em famílias de crianças com a paralisia cerebral. In. Albuquerque, R. D. L. e Risuenho, S.E (Orgs). Inclusão de pessoas com deficiência no contexto amazônico, Belém: L\&A Editora.

11. Organização Mundial da Saúde OMS (2003) Classificação internacional de funcionalidade, incapacidade e saúde. Revista Brasileira de Saúde Ocupacional 35(121): 1590/S0303-76572010000100013.

12. Santos ES, Díaz F, Bordas M, Galvão N, Miranda T (2009) Educação inclusiva, deficiência e contexto social: questões contemporâneas. Salvador: EDUFBA, Brazil.

This work is licensed under Creative Commons Attribution 4.0 Licens DOI: 10.19080/GJIDD.2017.01.555569
13. IBOPE NO (2013) Acesso à internet no Brasil atinge 94, 2 milhões de pessoas.

14. Andrade EMLR (2014) Avaliação do Ambiente Virtual de Aprendizagem no Ensino de Fisiologia em um Curso de Licenciatura em Enfermagem. Ribeirão Preto, Brasil: Escola de Enfermagem de Ribeirão Preto da USP.

15. Chorbev I, Sotirovska M, Mihajlov D (2011) Virtual communities for diabetes chronic disease healthcare. Int J Telemed Appl 2011(2011): $1-7$.

16. Sousa P, Fonseca H, Gaspar P, Gaspar F (2015) Usability of an internetbased platform for adolescent weight management. J Pediatr Rio J 91(1): 68-74.

17. Faleiros F, Pelosi G, Warschausky S, Tate D, Käppler C, et al. (2016) Factors Influencing the Use of Intermittent Bladder Catheterization by Individuals with Spina Bifida in Brazil and Germany. Rehabil Nurs doi:10.1002/rnj.302.

18. Favoretto NB (2015) Development of a virtual forum for individuals with spina bifida and their families: cooperation and technology transfer between Brazil and Germany; Thesis for the PhD in Rehabilitation at the Faculty of Rehabilitation Sciences of the University of DortmundGermany October-2015.

\section{Your next submission with Juniper Publishers will reach you the below assets}

- Quality Editorial service

- Swift Peer Review

- Reprints availability

- E-prints Service

- Manuscript Podcast for convenient understanding

- Global attainment for your research

- Manuscript accessibility in different formats

( Pdf, E-pub, Full Text, Audio)

- Unceasing customer service

Track the below URL for one-step submission https://juniperpublishers.com/online-submission.php 